\title{
内部改質方式溶融炭酸塩形燃料電池スタックの開発
}

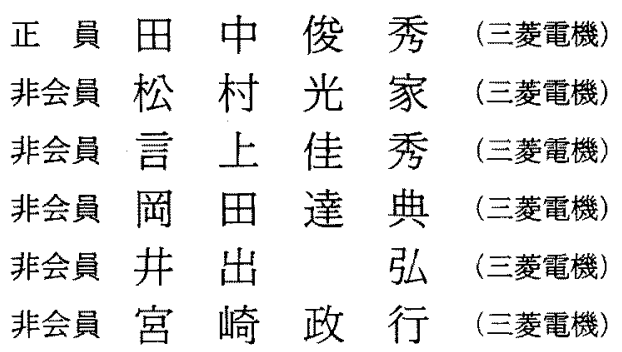

\section{Development of Internal Reforming Molten Carbonate Fuel Cell Stacks} Toshihide Tanaka, Member, Mitsuie Matsumura, Non-member, Yoshihide Gonjo, Nonmember, Tatsunori Okada, Non-member, Hiromu Ide, Non-member, Masayuki Miyazaki, Non-member (Mitsubishi Electric Corporation)

In Mitsubishi Electric, two types of internal reforming molten carbonate fuel cell (IR-MCFC) are being developed in parallel, e. $g \cdots$, Direct Internal Reforming (DIR) and Indirect Internal Reforming (IIR). Recently, a $3 \mathrm{~kW}$ DIR and a $10 \mathrm{~kW}$ IIR stacks have been built and tested. The main objectives of the stacks are to investigate the thermal balance in the stacks as well as full scale size cell and stack technologies.

The $3 \mathrm{~kW}$ DIR stack have attained a good performance as high as $0.799 \mathrm{~V}$ of average cell voltage at $150 \mathrm{~mA} / \mathrm{cm}^{2}$ of current density and more than $0.7 \mathrm{~V}$ even at $200 \mathrm{~mA} / \mathrm{cm}^{2}$. After the achievement of initial tests on various operating conditions, the stack has operated as long as 5,070 hours.

The $10 \mathrm{~kW}$ IIR stack has also showed a good performance. Especially, the degradation rate of cell voltage was as low as $5 \mathrm{mV} / 1,000 \mathrm{~h}$.

キーワード: 燃料電池, 溶融炭酸塩, 内部改質, スタック, 改質触媒

\section{1.まえがき}

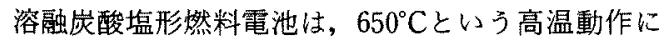
よって $45 \%$ 以上の高い発電効率が得られること，電 極反応が活発で白金触媒が不要なこと，天然ガスやメ タノールなどの炭化水素に加えて石炭力不化ガスも燃 料として利用できることなど，多くの特長をもってい る。なかでも，高温動作であることを有効に利用し て, 燃料の天然ガスを, 電池内部で水素を主成分とす るガスに変換する改質反応を行う内部改質方式の溶融 炭酸塩形燃料電池は，50〜60\%の高い発電効率が期待 できる(1)ことや，プラントの簡素化が図れるなど， 優れた特長をもっている。このような特長に着目し， 三菱電機では内部改質方式溶融炭酸塩形燃料電池 (以
下, 内部改質電池と呼ぶ)の実用化を目指し, 研究開 発を進めている。

内部改質電池には, 改質触媒を電池内部に直接設置 する直接形と, 触媒を容器に充てんして電池本体に組 込んだ間接形がある。これらの積層電池(スタック)の 開発で, 常圧動作の $3 \mathrm{~kW}$ 級直接形と $10 \mathrm{~kW}$ 級間接 形のスタックを試作し，運転評洒を実施した。

\section{2. 内部改質電池の形式と動作原理}

図 1 亿外部改質方式, 直接内部改質方式, 間接内部 改質方式の構造および動作原理を示す。溶融炭酸塩形 燃料電池の電解質層は, 動作温度 $\left(650^{\circ} \mathrm{C}\right)$ において溶 融状態にある炭酸塩(例えば, $\left.\mathrm{Li}_{2} \mathrm{CO}_{3} / \mathrm{K}_{2} \mathrm{CO}_{3}\right)$ で, 優 れたイオン導電性 $\left(\mathrm{CO}_{3}{ }^{2-}\right)$ を有している。外部回路を 


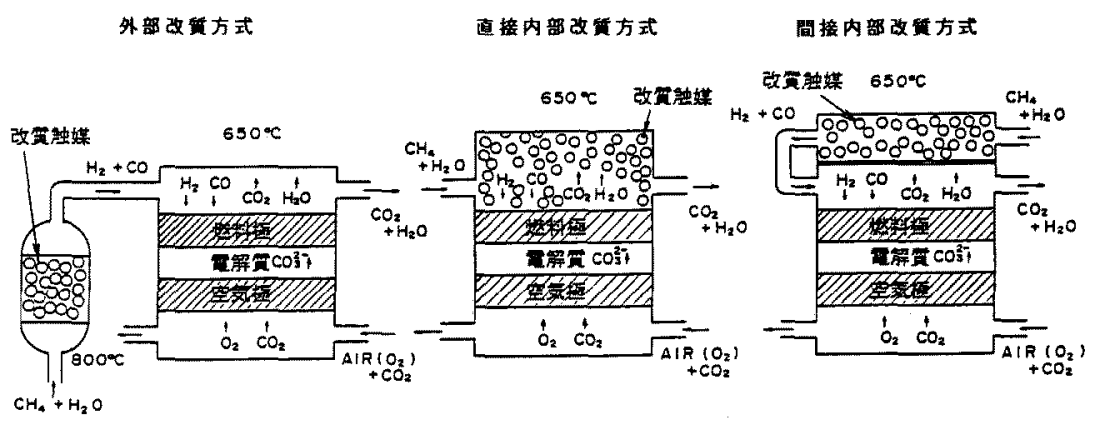

図 1 溶融炭酸塩形燃料電池の改質方式

Fig. 1. Types of reforming for molten carbonate fuel cell.

介してアノード (燃料極) 扝よびカソード(空気極)を接 続すると，アノードでは水素が酸化され，カソードで は酸素が還元されて, 両電極を合せると水素の酸化反 応が電気化学的に進行する。その際の化学エネルギー 変化の一部は電気的な仕事として取出され, 残りは熱 エネルギーとなる。アノードにおいては水素を電気化 学反応の燃料として利用するため, 原燃料が天然がス などの炭化水素や，またはアルコール類である場合に は，水蒸気改質反応によって水素を主成分とするガス に変換した後アノードに供給する。

外部改質方式では，原燃料を電池の外部に設置した 改質器に通して, 水蒸気改質反応により改質した後, 電池に供給する。一方，直接内部改質電池とは両電極 と電解暂層によって構成される通常の溶融炭酸塩形燃 料電池に加えて, 燃料ガス室に改質触媒を設置するこ とにより同ガス室において水蒸気改質反応を起こす機 能をもたせた電池である。直接内部改質電池は，電池 内部で電池反応と改質反応を並行して進行させる ため,

（1）電池反応による発熱を改質反応に有効に利用 することにより，更に発電効率が高くなる。

（2）電池と改質器との一体化に上り, 簡単なシス テムでコンパクトな構成が実現できる。

（3）改質反応の進行に並行して, 電極反応におい て水素を消費するため，比較的低温度でも十分 な改質反応が行える。

（4）電池反応によって生成されるスチームは, 再 び改質反応に利用でさるため，低スチーム・カ 一ボン比で動作させることがでさる。

など，多くの特長をもっている。

しかし, 電池内部に設置した改質触媒は電解質によ つて触媒の活性が通常より速く低下し, 電池寿命に大 きな影響を受ける。この対策として, 新規改質触媒の
開発，電解質の付着しにくい触媒充てん構造の検討な どを進めているが,その一手法に間接内部改質がある。 間接内部改質方式とは, 間接内部改質器に触媒を充 てんし，数枚の電池(セル)によって挟み込むことによ り, 電池反応によって発生する熱を有効に利用して改 貿反応を起こさせるものである。この方式では，直接 内部改質電池の前記 $(3)$ および (4)の利点はなくなる ものの, 改質触媒が電解質雲囲気から隔離されるので 触媒の被毒を回避でき, 直接形に比べ長寿命化が期待 できる。

\section{3. $3 \mathrm{~kW}$ 級直接内部改質電池スタック}

直接内部改質電池の開発では, 改質触媒の活性低下 機構の解明, 単電池およびスタックによる運転評価な ど幅広い研究開発を進めてきている(2)。特に, 平成 2 年には, スタック内部に抢ける電池反応(発熱反応) と, 改質反応 (吸熱反応)との熱的なバランスを実証す ると共に，電池の大容量化に対する課題を検討するた め, 有効電極面積が $5,016 \mathrm{~cm}^{2}$ のセル 5 枚による $3 \mathrm{~kW}$ 級スタック(コードネーム:DIR 50-1)を試作 し，5,070 時間に方たる運転評洒を実証した。本ス夕 ックの外観を図 2 に示す。

$\langle 3 \cdot 1\rangle$ 発電特性 DIR 50-1 の電圧-電流密度特 性を図 3 に示す。燃料のメタンガス供給流量は, 電流 密度 $200 \mathrm{~mA} / \mathrm{cm}^{2}$ において燃料利用率 $80 \%$ 一定とし ており, 定格電流密度 $150 \mathrm{~mA} / \mathrm{cm}^{2}$ においては燃料 利用率 $60 \%$ となっている。一方, 酸化剂がスには空 気 $/ \mathrm{CO}_{2}=70 / 30$ で, 利用率はスタック冷却のため, 力 ソードガスリサイクル動作状態での值で $20 \%$ 一定で ある。図 3 に示すように，開路電圧はどのセルも $1.075 \mathrm{~V}$ 以上あり，理論計算值に等しく，供給したメ タンガスが水素に十分改質されていることがわかる。

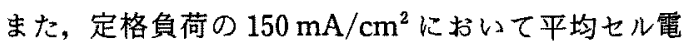




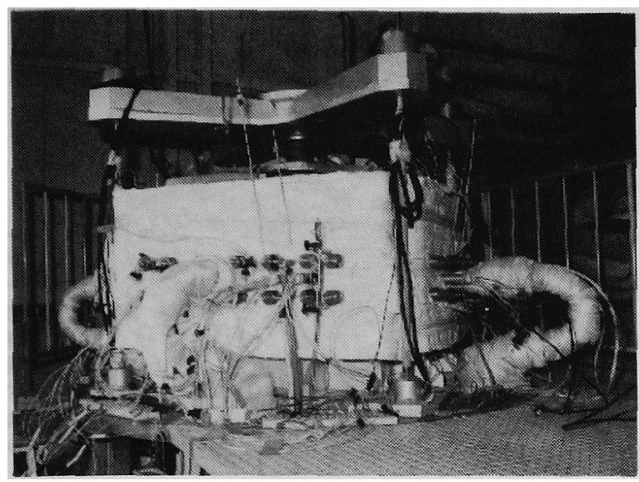

図 $23 \mathrm{~kW}$ 級直接内部改質電池スタックの外観

Fig. 2. Partial view of a $3 \mathrm{~kW}$ DIR-MCFC.

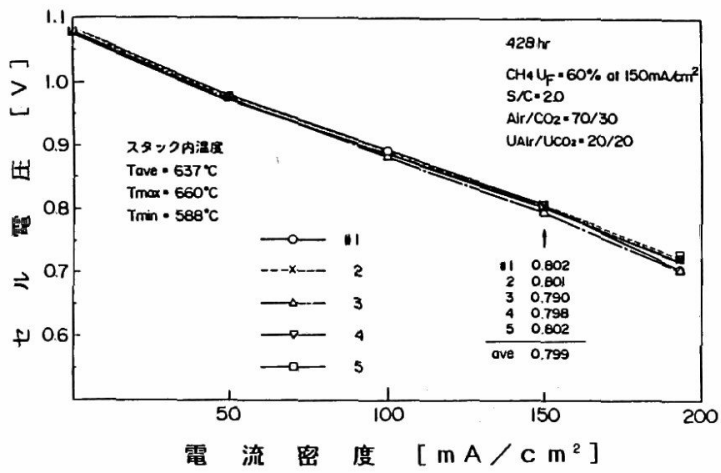

図 4 平均セ儿電圧の燃料利用率依存性

(DIR 50-1)

Fig. 4. Fuel utilization dependence on average cell voltage (DIR 50-1).

圧 $0.799 \mathrm{~V}$ を達成し, セル間のばらつきも $10 \mathrm{mV}$ 程 度と非常に良くそろっている。更に $195 \mathrm{~mA} / \mathrm{cm}^{2}$ (負 荷装置の動作範囲の都合により, $200 \mathrm{~mA} / \mathrm{cm}^{2}$ は計測 できなかった)においても平均セル電圧が $0.7 \mathrm{~V}$ 以上 と, 高電流密度においても十分運転可能なことを示し ている。ちなみに, 溶融炭酸塩形燃料電池では, 運転 可能なセル電圧の下限を現在のところ $0.6 \mathrm{~V}$ とて いる。

〈3.2〉燃料利用率依存性 図 4 に DIR 50-1 の $150 \mathrm{~mA} / \mathrm{cm}^{2}$ における燃料利用率依存性を示す。この スタックでは，短時間的には燃料利用率を $90 \%$ まで 上げても, 平均セル電圧は $0.7 \mathrm{~V}$ 以上を保持し, 十 分運転が可能である。

文献 (3) による燃料利用率依存性の式 (4.20)

$$
\Delta V_{F}(\mathrm{mV})=173 \log \frac{\left[\bar{P}_{\mathrm{H}_{2}} / \bar{P}_{\mathrm{CO}_{2}} \bar{P}_{\mathrm{H}_{20} 0}\right]_{2}}{\left[\bar{P}_{\mathrm{H}_{2}} / \bar{P}_{\mathrm{CO}_{2}} \bar{P}_{\mathrm{H}_{20}}\right]_{1}}
$$

電学論B, 112 卷 8 号, 平成 4 年

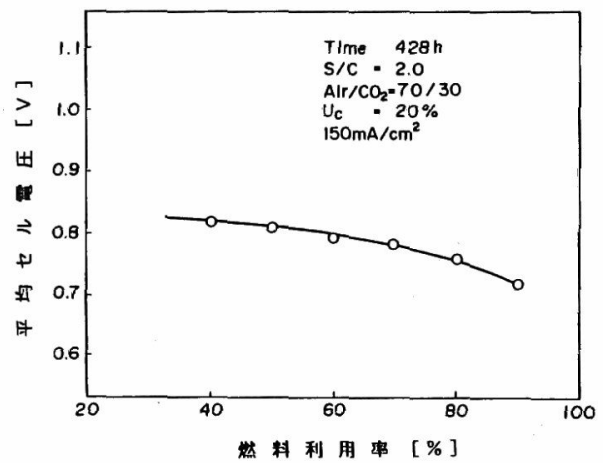

図 3 セ儿電圧-電流密度特性 (DIR 50-1)

Fig. 3. Stack performance of DIR 50-1.

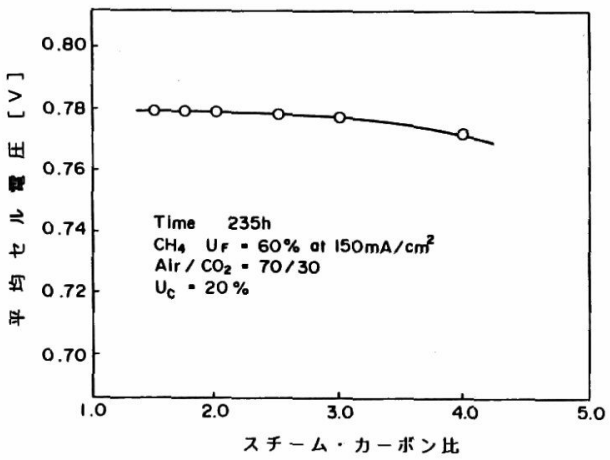

図 5 平均セル電圧の $S / C$ 依存性 Fig. 5. $S / C$ dependence on average cell voltage.

によれば，燃料利用率を $40 \%$ から $80 \%$ に上昇させた 場合，アノードゲインによる電圧の減少は約 $76 \mathrm{mV}$ である。しかし，図4 に扔ける測定値では，熱料利用 率 $40 \%$ と $80 \%$ における電圧の差は約 $60 \mathrm{mV}$ と少し小 さい。この原因は, 燃料利用率が高くなるほど, 燃料 ガス流量低下に伴う冷却能力が低下し, スタック温度 が上昇しているためである。すなわち，図 4 では，燃 料利用率 40\%のときに比べ $80 \%$ においてはスタック 温度が約 10 度上昇しており, 文献 ( 3 )の温度依存性 の式(4.10)

$$
\Delta V_{T}(\mathrm{mV})=1.5\left(T_{2}-T_{1}\right)^{\circ} \mathrm{C}\left(600 \sim 650^{\circ} \mathrm{C}\right)
$$

によれば，この温度上昇によるセル電圧の上昇は，約 $15 \mathrm{mV}$ で，図 4 の測定值をよく説明できる。

\section{〈3・3〉 スチーム・カーボン比 $(S / C)$ 依存性}

燃料ガスに対するスチームの量を変えた場合のセル 電圧の変化を図 5 に示す。同図において $S / C$ が低く 
なるほど，平均セル電圧は高くなっている。これは， スチームの量が少なくなるにつれ，改質反応によって 作られる水素の分圧が上昇するためである。通常，外 部改質器では, カーボン析出を防止するため, $S / C$ を3〜4に設定して運転しているが，内部改質電池に おいては，電池反応によってアノード側に発生する水 蒸気を有効に利用できるため, 低 $S / C$ で運転するこ とができる。この低 $S / C$ 運転によるセル電圧の向上 は，結果的にシステムの発電効率を高くすることがで き，これが内部改質電池の大きな特長の一つである。 実際, DIR 50-1では，S/C=1.5 まで低下させても 十分運転可能であることを示している。

〈3.4〉 温度分布, 改質率分布, 電流密度分布

スタックの上部端セル(\#1セル)面内に抢ける燃料 ガス流れ方向の温度分布, およびガス分析によって算 出される改質率分布と電流密度分布の結果を図 6 に示 す。同図が示すように，本スタックではメタンの改質 反応は燃料ガスの入口部分で集中して進行し，流路の 約 1/8 流れた時点でほとんど改質反応が終了してい る。一方, 電池反応梳比較的広範囲に平均して進行し ており, 従って発熱量も相対的に広範囲に平均して存 在する。内部改質電池の場合は, 特にこれらの電池反 応による発熱と改質反応による吸熱の熱バランスを制 御することが重要な課題である。

〈3.5〉経時特性 図 7 に平均セル電圧および改 質率の経時特性を示す。運転開始より2,000 時間程度 まで安定した特性を示している。2,250 時間において スタックをいったん常温まで降温し，燃料ガスの流れ をタロスフローからリターンフローに変更した。その 結果, 面内温度分布の均一化やリターンマニホールド 内での未改質ガスの混合効果による改質率の向上など により，負荷時セル電圧が約 $10 \mathrm{mV}$ 改善された。一 方，2,250 時間以降，時間と共にセ儿電圧が低下して いる。これは, 主に電解質板内へのニッケル析出によ るセルの電気的短絡現象の増加が原因である。特に, 開路電圧が低下するのは，外部負荷をとらなくても電 池内部で負荷をとった状態になるためであり，このこ とはアノードガス出口に㧍いて， $\mathrm{N}_{2}$ 分圧が時間的に 変化せず $\mathrm{CO}_{2}$ の分圧のみが増加していることによっ ても確認されている。

メタン改質率は 4,130 時間においても95\%以上を示 し，触媒活性がまだ十分であることがわかる。しか し，4,770時間においてがス供給系のトラブルにより 炭酸ガスが長時間にわたって停止し, 電池特性に大き な影響を与えた。そこでいったん常温状態に戻して スタックの修理や電解質の補給を実施して再立上げを

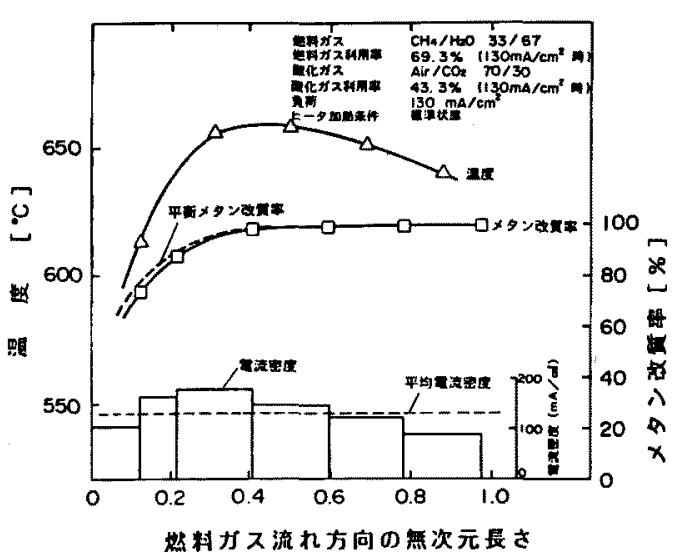

図 6 温度, 改質率, 電流密度分布 (\#1 セル) Fig. 6. Temperature, methane conversion and current density profile ( 1 cell).
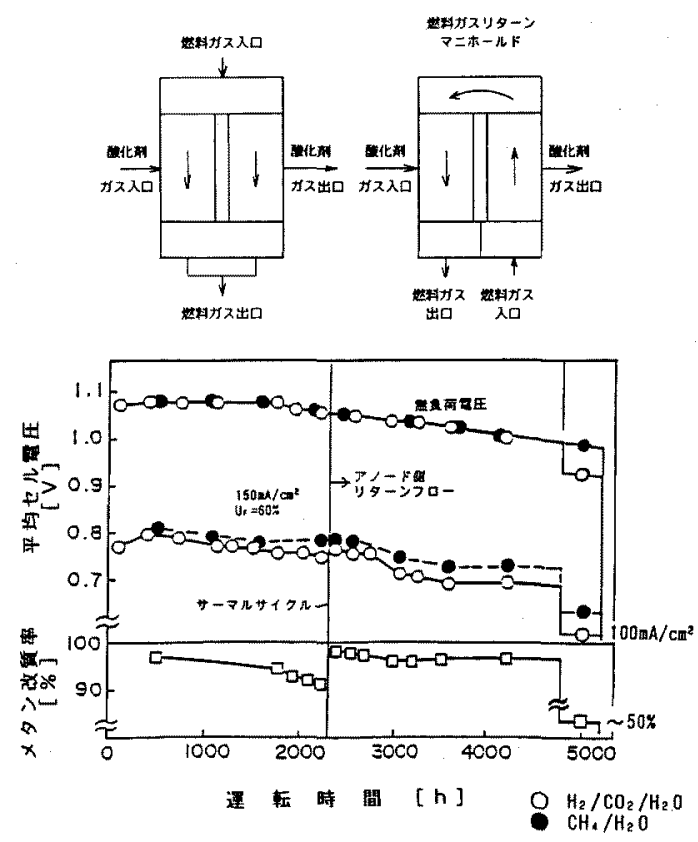

図 7 発電特性の経時変化

Fig. 7. Operating record of DIR 50-1.

行った結果, 改質触媒の活性は十分でないものの, 発 電可能な状態まで復帰したため, 引続き運転を行い当 初目標の 5,000 時間運転を達成した後，5,070 時間で 試験を終了した。

\section{4. $10 \mathrm{~kW}$ 級間接内部改質電池スタック}

最初の間接内部改質電池スタック(コードネーム： 


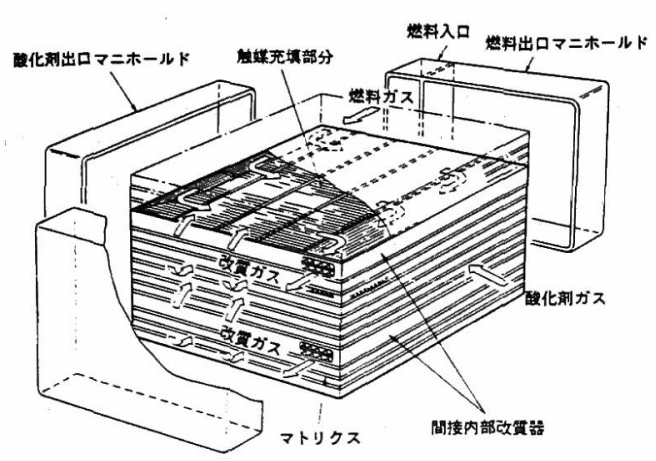

図 8 IIR 50-2 の構造

Fig. 8. Stack configuration of IIR 50-2.

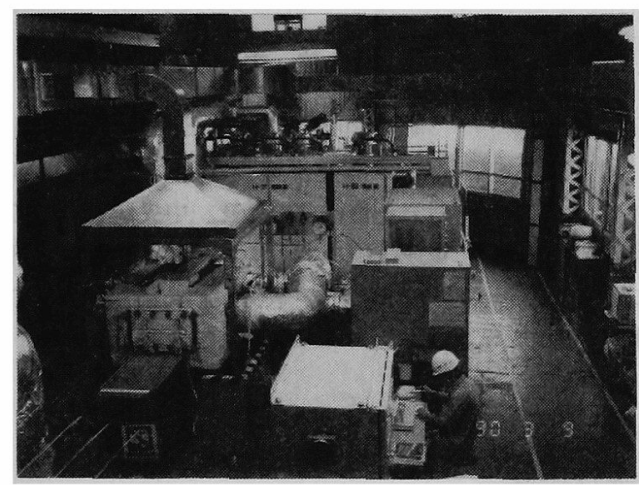

図 $910 \mathrm{~kW}$ 級間接内部改質電池の試験風景

Fig. 9. Whole view of IIR 50-2 testing.

IIR 50-1，3.6 kW) は，間接内部改質の機能を検証す るために平成元年に試作され，2,185 時間にわたって 運転評価を実施された ${ }^{(3)}$ 。その試験結果を基に，ス夕 ックおよび間接改質器内部の温度分布の改善のための 検討などを行い, 更に複数の間接内部改質器とセルを 高く積層したスタックの基本特性を確認するために, 平成 2 年には $5,016 \mathrm{~cm}^{2}-20$ セルによる $10 \mathrm{~kW}$ 級ス夕 ック(コードネーム：IIR 50-2)を試作した。本スタッ クは間接内部改質器 3 個を 4 セル -6 セル -6 セル -4 セ ルの間隔で挟み込んだもので，その構造とガスの流れ を図 8 に, 試験風景を図 9 に示す。

〈4・1〉 発電特性 IIR 50 2 に燃料として標準ガ ス $\left(\mathrm{H}_{2} / \mathrm{CO}_{2} / \mathrm{H}_{2} \mathrm{O}=72 / 18 / 10\right.$ の混合ガス)を投入した 場合(以下， RG モードと呼ぶ)，抢よびメタン $\left(\mathrm{CH}_{4}\right.$, $S / C=3.0 \sim 5.1$ )を投入した場合(以下, IIR モードと 呼ぶ)の平均セル電圧-電流密度特性を図 10 に示す。 IIR モード $\left(\mathrm{CH}_{4}, S / C=4.0\right)$, 電流密度 $150 \mathrm{~mA} /$ $\mathrm{cm}^{2}$, 燃料利用率 $\left(U_{\mathrm{F}}\right) 60 \%$ において, 平均セル電圧は

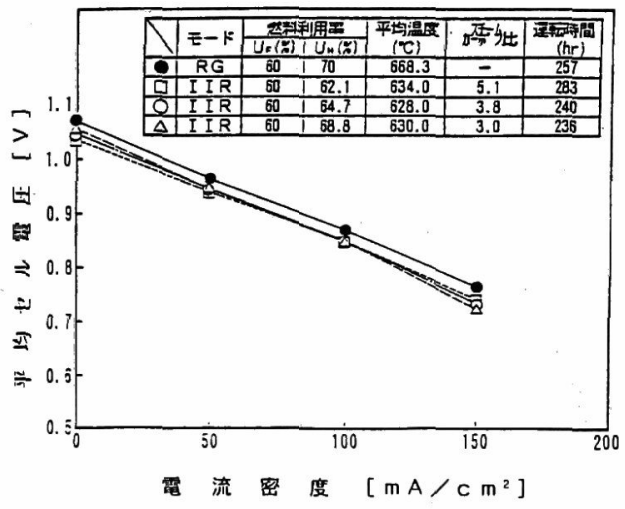

図 10 平均セル電圧-電流密度特性

Fig. 10. Stack performance of IIR 50-2.

$0.742 \mathrm{~V}$ となっている。DIR 50-1 の発電特性に比較 して, IIR 50-2 の発電特性が低いのは単にスタックが 大形化しただけではなく，次のような要因も考えられ る。まず RG モードにおいては, 燃料として同じ組成 の標準ガスを供給しても，間接内部改質器においてメ タネーション反応によりメタンを発生し，アノードに 供給されるガスの水素分圧が低下するためである(こ の現象は間接内部改質器出口のガス分析によっても確 認されている)。更に IIR モードが RG モードに比較 して $27 \mathrm{mV}$ 低くなっているのは，IIR モードにおい て改質反応による吸熱がスタック動作温度を低下させ たためである。

なお間接内部改質の場合, 改質率は電池の動作温度 における平衡組成にまでしか到達しないため, 電池内 部に扔ける実質の燃料利用率(水素利用率： $U_{\mathrm{H}}$ ) が高 くなる。従って, 高い改質率を得るためには直接内部 改質よりは高い $S / C$ で運転する必要がある。

〈4・2〉温度分布 IIR 50-1の運転評価において 明かにされた開発課題の一つに間接内部改質器および スタック内部の温度分布がある。一般的に溶融炭酸塩 形燃料電池スタックの運転温度は, 下限が電解質の溶 融温度 $520^{\circ} \mathrm{C}$, 上限が電池構成部材の観点から $700^{\circ} \mathrm{C}$ に制限される。従って, 現在スタッタ内温度分布はで きるだけ 550〜 $680^{\circ} \mathrm{C} に$ 収まるように制御している。 しかし, IIR 50-1 に扔けるセル内温度差は最大 $126^{\circ} \mathrm{C}$ であった。しかも，セル内の最大温度は $698^{\circ} \mathrm{C}$ と少し 高かった。この問題を解決するためにシミュレーショ ンにより間接内部改質器の構造の最適化を検討し，そ の検討結果に基づき, IIR 50-2 では改質器の構造を改 良して改質器内温度分布の改善を図った。その結果, セル内温度差は約 $30^{\circ} \mathrm{C}$ 低下し $90^{\circ} \mathrm{C} に$ まで抑えること 


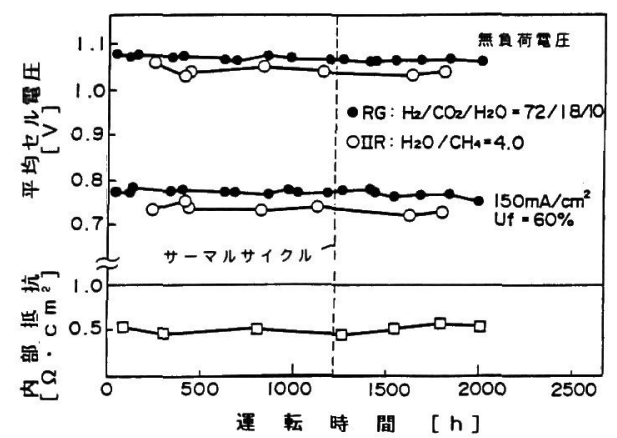

図 11 発電特性の経時変化

Fig. 11. Operating record of IIR 50-2.

ができた。

〈4・3〉 経時特性 IIR 50-2 は，2,052 時間にわた つて安定に運転された。そのスタック特性の経時変化 を図 11 に示す。運転終了後のセル電圧の低下率は $5 \mathrm{mV} / 1,000 \mathrm{~h}$ で, 通商産業省工業技術院ムーンライト 計画第 II 期計画の中間評価において目標としている $1 \% / 1,000 \mathrm{~h}(8 \mathrm{mV} / 1,000 \mathrm{~h})$ を満足している。また, 1,200 時間では室温まで降温し, 再び昇温した。この 一度のサーマルサイクルでは, スタック特性はほとん ど影響を受けていない。

\section{5. まと め}

以上, $3 \mathrm{~kW}$ 級直接形および $10 \mathrm{~kW}$ 級間接形の内 部改質電池スタックの試験結果についてまとめた。現 在までのところ, 得られたデータは，ほとんど内部改 質電池発電システムの実現に対し希望のもてるもの で, 特に達成不可能な課題は見あたらない。今後, 更 に高積層技術の検討やフルサイズスタック（数十 〜 $100 \mathrm{~kW}$ 級) の開発を経て, 発電システムの実現を 目指している。

一方, 発電システムの実現に対しては, 電池本体の みならず，システムを構成する要素技術の開発も重要 であり，スタックの運転評価技術の開発も含めて，鋭 意研究開発を進めている。

なお本研究において, 直接内部改質電池の開発は通 商産業省工業技術院ムーンライト計画の一環として新 エネルギー・産業技術総合開発機構(NEDO)から委託 を受けて, 実施したものであり, 間接内部改質電池の 開発は, 関西電力との共同研究として実施したもので ある。

(平成 3 年 11 月 8 日受付)

\section{文献}

(1) T. Tanaka, M. Murahashi, E. Nishiyama \& I. Hirata: "Molten Carbonate Fuel Cell Development and System Analysis", Proc. of 21st IECEC, p. 1100 (1986)

(2) T. Tanaka, M. Matsumura, Y. Gonjo, C. Hirai, T. Okada \& M. Miyazaki : "Development of Internal Reforming Molten Carbonate Fuel Cell Technology", Proc. of 25th IECEC, Vol. 3, p. 201 (1990)

(3) T. G. Benjamin, E. H. Camara \& L. G. Marianowski : "Handbook of Fuel Cell Performance", US DOE Report, Project 61012 (1980)

(4) T. Okada, H. Ide, M. Miyazaki \& T. Tanaka : "Study of Temperature Control in Indirect Internal Reforming MCFC Stack", Proc. of 25th IECEC, Vol. 3, p. 207 (1990)

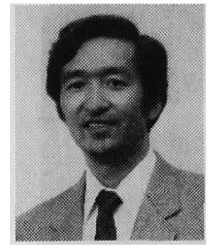

\section{田中俊 秀 (正員)}

昭和 20 年 7 月 29 日生。 44 年 3 月京 都大学工学部電気工学科卒業。 45 年 4 月三菱電機 (株) 入社。中央研究所にて高 電圧技術, エネルギー機器に関する研究 に従事, 59 年より燃料電池技術の研究開発を担当。工学 博士。静電気学会, プラズマ・核融合学会会員。

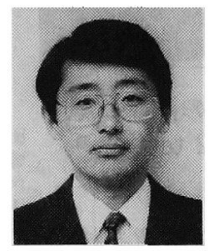

協会会員。

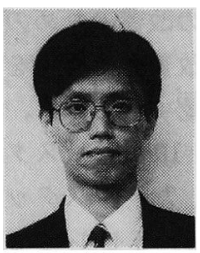

本機械学会会員。

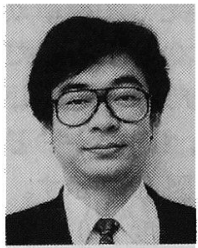

機械学会会員。

\section{松 村 光 家 (非会員)}

昭和 29 年 12 月 26 日生。 55 年東京大 学大学院工学系研究科卒業。同年 4 月三 菱電機 (株) 入社。中央研究所にて燃料電 池技術の研究開発に従事。日本化学工学

\section{言 上 佳 秀 (非会員)}

昭和 34 年 1 月 2 日生。 59 年 3 月京都 大学大学院工学研究科物理工学科卒業。 同年 4 月三菱電機 (株) 入社。中央研究所 にて燃料電池技術の研究開発に従事。日

\section{岡田達 典(非会員)}

昭和 34 年 4 月 28 日生。 58 年 3 月東 北大学工学部精密工学科卒業。同年 4 月 三菱電機 (株) 入社。以来, 中央研究所に て燃料電池技術の研究開発に従事。日本 


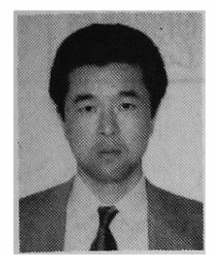

学協会会員。

\section{井出弘 (非会員)}

昭和 30 年 9 月 28 日生。 56 年東京工 業大学大学院化学工学科卒業。同年 4 月 三菱電機 (株) 入社。中央研究所にて燃料 電池技術の研究開発に従事。日本化学工

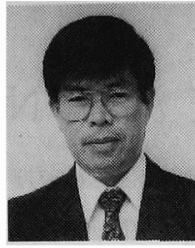

宮 崎 政 行（非会員）

昭和 24 年 8 月 1 日生。 43 年 3 月大阪 府立今宮工業高校機械科卒業。同年 4 月 三菱電機(株)入社。中央研究所几て, 機 器の高温強度に関する研究開発に従事 し, 62 年より燃料電池の研究開発を担当。日本機械学会 会員。 